Article

\title{
Innovation in Tigernut (Cyperus Esculentus L.) Milk Production: In Situ Hydrolysis of Starch
}

\author{
Djomdi $1, *$, Bakari Hamadou ${ }^{1,2}$, Olivier Gibert ${ }^{3}$, Thierry Tran ${ }^{3,4}{ }^{\oplus}$, Cedric Delattre ${ }^{5}(\mathbb{C}$, \\ Guillaume Pierre ${ }^{5}{ }^{D}$, Philippe Michaud ${ }^{5, *}{ }^{-}$, Richard Ejoh ${ }^{6}$ and Robert Ndjouenkeu ${ }^{6}$
}

1 Department of the Renewable Energies, The National Advanced School of Engineering of Maroua, University of Maroua, Maroua P.O.Box 46, Cameroon; hamadou.bakari@yahoo.fr

2 Energy Research Laboratory, Renewable Energy Section (LRE/SENC), Institute for Geological and Mining Research (IRGM), Nlongkak Yaounde P.O.Box 4110, Cameroon

3 UMR Qualisud, University of Montpellier, CIRAD, Montpellier SupAgro, University of Avignon, University of La Réunion, 73 rue JF Breton, 34398 Montpellier, France; olivier.gibert@cirad.fr (O.G.); thierry.tran@cirad.fr (T.T.)

4 The Alliance of Bioversity International and the International Center for Tropical Agriculture (CIAT), CGIAR Research Program on Roots Tubers and Bananas (RTB), Apartado Aéreo 6713, Cali 763537, Colombia

5 Université Clermont Auvergne, CNRS, SIGMA Clermont, Institut Pascal, F-63000 Clermont-Ferrand, France; cedric.delattre@uca.fr (C.D.); guillaume.pierre@uca.fr (G.P.)

6 Depantment of Food Science and Nutrition, University of Ngaoundéré, Ngaoundéré P.O.Box 455, Cameroon; rabejoh@yahoo.com (R.E.); rndjouenkeu@yahoo.fr (R.N.)

* Correspondence: ngdjomdi@yahoo.fr (D.); philippe.michaud@uca.fr (P.M.); Tel./Fax: +237-222-29-31-12 (D.); +33-473-4074-25 (P.M.)

Received: 5 June 2020; Accepted: 18 June 2020; Published: 23 June 2020

\begin{abstract}
Tigernut tubers (Cyperus esculentus) are used for the production of vegetable milk, commonly known as "Horchata de chufa" in Spain. The presence of starch in the tuber limits the yield of the milk, since this carbohydrate gelatinizes during the pasteurization of the milk and leads to the considerable solidification of this drink. The present work aims to improve the yields and extraction practice of the milk by an in situ hydrolysis of starch, using exogenous amylases of industrial or vegetable origin. The obtained results show that sprouting improves the extraction yields of tigernut milk, which goes from $50 \%$ to about $70 \%$. This improvement in milk yield corresponds to a hydrolysis of about $35 \%$ of the starch in the tuber. The use of exogenous amylases leads to starch hydrolysis rates of $45 \%$ and $70 \%$, respectively, for amylolytic extracts from sprouted tigernut tubers and amylase, with the corollary of a natural increase in the sweetness of milk. This technical approach makes it possible to produce a naturally sweetened tigernut milk which easily lends itself to pasteurization without a significant increase in viscosity.
\end{abstract}

Keywords: Cyperus esculentus; sprouting; carbohydrates; amylases; depolymerization; sweetness

\section{Introduction}

Tubers are foodstuffs that contain more starch, by dry weight, than almost all other food crops [1]. Many authors have shown that Cyperus esculentus L. is an edible plant which produces tubers containing an important starch quantity (about 30-40\%) [2-4]. These tigernut tubers are used in Spain for the production of a milky drink called hochata de chufa $[5,6]$. This drink does not lend itself well to thermal sanitation treatments due to the gelatinization and retrogradation of its starchy component during pasteurization and cooling. This constraint induces, in the technical practices for producing horchata, either an elimination of the pasteurization operation of the milky drink, which reduces its capacity for preservation, or a complementary decanting operation to eliminate the starchy compound, 
with consequently reduces the nutritional value of the drink $[7,8]$. In both cases, sugar is added at the drink to improve the taste.

Various studies $[3,7,9]$ have shown interest in the sprouting of tigernut tubers, especially in the production of malted flour. This operation leads to a hydrolysis of starch into free sugars, which can be used to reduce the risk of gelatinization of carbohydrate compounds during the production and pasteurization of the milky drink. In the same order of ideas, the in situ hydrolysis of the tigernut starch tubers can be considered by adding industrial amylases during the production of the beverage.

The objective of this study is therefore to improve the yield and extraction practice of tigernut milk; which constitutes an innovative opportunity through the production of this drink from sprouting tubers or by the addition of exogenous amylases. The interest of the study lies in the possibility of offering a naturally sweetened drink with no obligation to add sugar and which easily lends itself to pasteurization.

\section{Material and Methods}

\subsection{Sample Origin}

The experiments were carried out on tigernut tubers $\varnothing>1 \mathrm{~cm}$ bought in the market from the locality of Guili (Mokolo, Savannah Region of the Far North of Cameroon).

\subsection{Sample Traitments}

The tubers were subjected to soaking treatments in vitamin C solution (SVT), and part of the soaked tubers was subjected to sprouting (ST). Untreated tubers or Native Tubers (NT) were used as controls.

\subsubsection{Vitamin C Treatment}

This treatment consisted of soaking the tigernut tubers in the vitamin $\mathrm{C}$ solution $(1 \mathrm{~g} / \mathrm{L})$ at $40{ }^{\circ} \mathrm{C}$ for $48 \mathrm{~h}$, the time necessary for their maximum swelling.

\subsubsection{Tubers Sprouting}

The tigernut tubers were sprouted according to the methods developed by Umerie et Enebeli [9] and Garcia Jiménez et al. [10]. For this purpose, the tubers soaked in the solution of vitamin $\mathrm{C}$ for $48 \mathrm{~h}$ at $40{ }^{\circ} \mathrm{C}$ were put for sprouting at $25^{\circ} \mathrm{C}$ on jute bags protected from light for 6 days and sprayed with water two times a day (morning and evening). It should be noted that treatment with vitamin $C$ is also a treatment for the destruction of molds (Dematophora necatrix), agents for the inhibiting germination of tubers [10]. After germination, the tubers were dried for $48 \mathrm{~h}$ at $40{ }^{\circ} \mathrm{C}$ in an oven and the rootlets removed manually.

\subsubsection{Milk Extraction}

Different tigernut drinks ((NT), (SVT), and (ST)) were produced using a "horchata" machine (Moulin-Presse, H-MP 3, MEJISA MECTUFRY, la Mecanica Jijonenca Mectufry S.A.; Poligono de Segorb SN/03100 JIJONA, Alicante, Spain; Figure 1).

The hopper (C), where we pour the tigernut. Start button, (E). Tap, (F), to adjust the amount of water entering the machine. Milk discharge mouth or pipe, $(\mathrm{G})$. Valve, $(\mathrm{H})$, to empty the pressed pulp. Tank, (D), the interior of which contains a spinning wheel with grinding mallets; this rotating part allows grinding and maceration.

\subsubsection{In Situ Hydrolysis of Milk Starch}

Starch in the three obtained beverage samples was subjected to hydrolysis using two sources of amylases: a commercial enzyme, Termamyl, which is an alpha amylase; and amylolytic extracts from the sprouted tigernut tubers. 

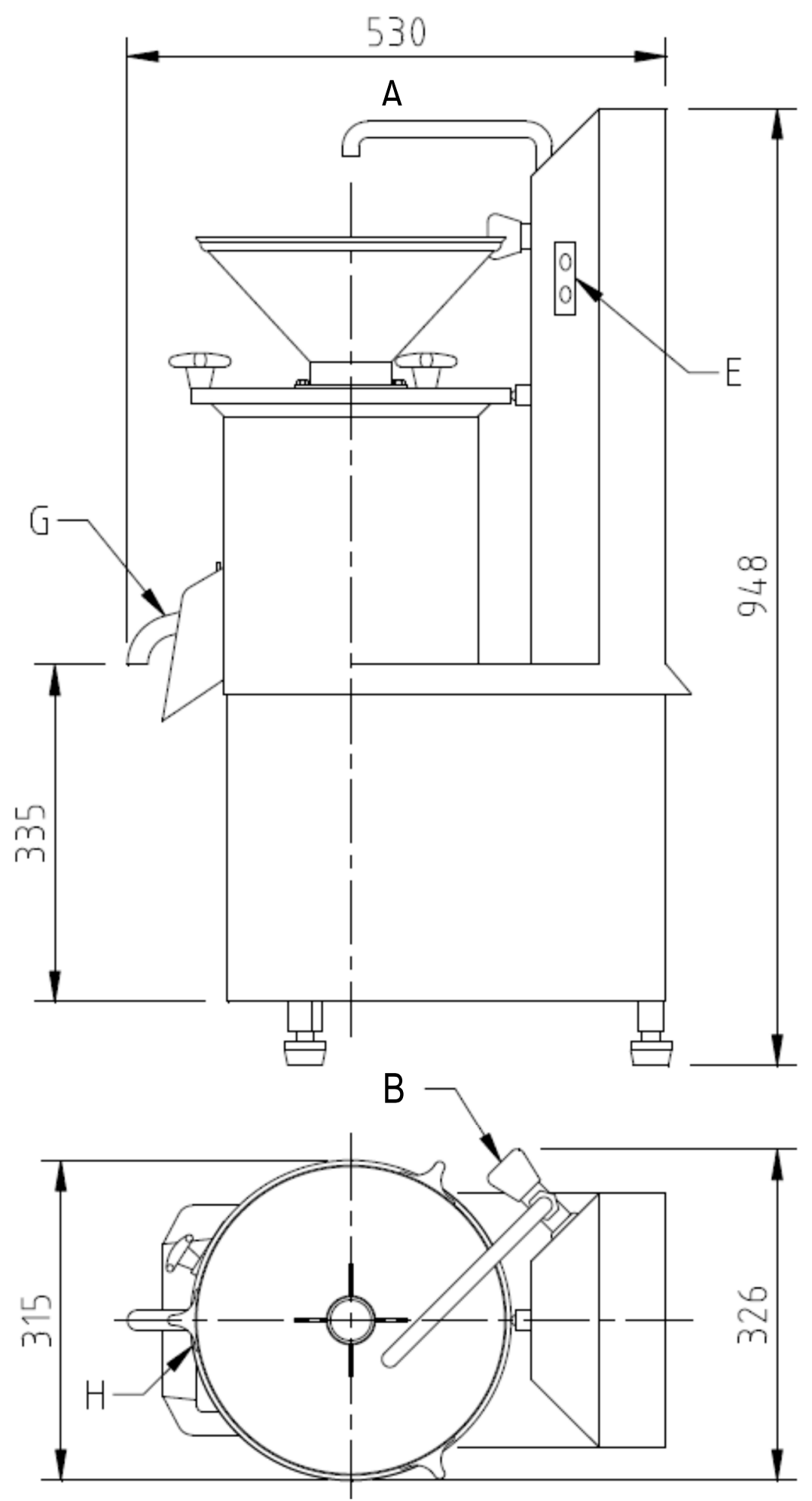

Figure 1. Diagram of the horchata machine (Moulin-Presse, H-MP 3) (A: front view; B: top view).

- Termamyl Hydrolysis Termamyl is an enzyme of bacterial origin; its characteristics are listed in Table 1.

To carry out this hydrolysis, $0.1 \mathrm{~mL}$ of Termamyl was applied to $100 \mathrm{~mL}$ of each sample contained in glass jars and kept under stirring conditions at the temperature of $80^{\circ} \mathrm{C}$ in s water bath for $180 \mathrm{~min}$. 
- Amylolytic extracts hydrolysis

- Amylolytic extracts preparation

An amount of $25 \mathrm{~g}$ of sprouted tigernut tubers was powdered using the Dangoumeau-type mill (Dangoumill 300, Lonjumeau, France) in the presence of $\mathrm{N}_{2}$, and the powder obtained was sieved $(500 \mu \mathrm{m})$. The powder obtained was transferred to a $250 \mathrm{~mL}$ flask and $150 \mathrm{~mL}$ of $\mathrm{NaCl}$ solution (5\%) was added. The mixture was stirred for $15 \mathrm{~min}$ using the magnetic stirrer and at room temperature $\left(25^{\circ} \mathrm{C}\right)$. The mixture was filtered using Whatman No. 1 filter paper $(9 \mathrm{~cm})$, and the volume of the filtrate obtained was completed with $\mathrm{NaCl}(5 \%)$ at gauge line in the $250 \mathrm{~mL}$ flask. The enzyme extract was used after $2 \mathrm{~h}$ of rest.

- Amylolytic extracts use

Extracts from the sprouted tubers were used as a source of amylolytic enzymes for in situ hydrolysis of starch in milky drinks. The $\mathrm{pH}$ of the milky extracts was kept at 6.8 during the tests. To carry out the hydrolysis of starch contained in milky drinks, $0.1 \mathrm{~mL}$ of enzyme extract was applied to $100 \mathrm{~mL}$ of each sample after heating at $80^{\circ} \mathrm{C}$ for $15 \mathrm{~min}$ and cooling at $45^{\circ} \mathrm{C}$. The mixture was kept under stirring conditions in glass jars at $45^{\circ} \mathrm{C}$ (a temperature which corresponds to the maximum activity of amylases of plant origin) [11] in the water bath for $180 \mathrm{~min}$.

- Hydrolysis kinetics

In situ hydrolysis and kinetic analysis of starch in the different milk samples was carried out according to the methods of Goni et al. [12] and Bellmer et al. [13]. According to these methods, $1 \mathrm{~mL}$ of each sample was taken every $20 \mathrm{~min}$ for $180 \mathrm{~min}$ to determine the starch content in the reaction medium.

Table 1. Characteristics of the exogenous enzyme used for starch hydrolysis.

\begin{tabular}{cccccc}
\hline Enzyme & Class & Origin & Optimal pH Activity & $\begin{array}{c}\text { Optimal } \\
\text { Temperature }\left({ }^{\circ} \mathrm{C}\right)\end{array}$ & Enzymatic Activity \\
\hline Termamyl 120 L & $\alpha$-amylase & Bacillus licheniformis & $5.8-7$ & $80-85$ & $120 \mathrm{KNU} \mathrm{g}^{-1 *}$ \\
\hline \multicolumn{5}{c}{${ }^{*} \mathrm{~kg}$ Novo $\alpha$-amylase Unit. }
\end{tabular}

\subsection{Physico-Chemical and Functional Analysis}

\subsubsection{Amylolytic Activities of Tigernut Tubers}

The amylolytic activities of the sprouted tiger tubers were determined by a spectrophotometric assay kit using amylase colorimetry (Megazyme International, County Wicklow, Ireland).

\subsubsection{Physico-Chemical Analysis}

Examinations of the protein, crude fiber, and lipid contents were carried out by the AFNOR standard methods [14]. The total energy was obtained by the method of Edem et al. [15]. The dry matter and ash contents were determined by the Union Internationale de Chimie Pure et Appliquée (UICPA) methods [16]. The starch content was determined by the method of Mestres and Mestres [17]. The vitamin E and ascorbic acid levels were determined by the (NP)-HPLC method [18] and the Association of Official Analytical Chemists (AOAC) method [19], respectively. The total carbohydrates and reducing sugar were determined by AOAC [19] procedures.

\subsubsection{Rheological Profiles of Milks}

Rheological measurements of the milky extracts were carried out on each sample using a dynamic rheometer (RHEOPLUS/32 V3.40 21004531-33056 Anton Paar, MCR 301 Physica, Virginia, USA). An amount of $15 \mathrm{~g}$ of each suspension of the milky extracts whose dry matter and starch contents 
varied from $17 \%$ to $19 \%$ and $3 \%$ to $12 \%$, respectively, were subjected to a temperature ramp (from 50 to $90{ }^{\circ} \mathrm{C}$ at a speed of $2{ }^{\circ} \mathrm{C} / \mathrm{min}$ ), the initial temperature being fixed at $50{ }^{\circ} \mathrm{C}$ and gradually increasing in steps of $2{ }^{\circ} \mathrm{C} / \mathrm{min}$ for a maximum of $90^{\circ} \mathrm{C}$. The temperature of the samples was maintained at this level for $5 \mathrm{~min}$, then they were cooled to $50^{\circ} \mathrm{C}$ in steps of $2{ }^{\circ} \mathrm{C} / \mathrm{min}$ and maintained at this level for $3 \mathrm{~min}$. The rheological profile data for the processed beverages was automatically saved by the computer connected to the rheometer and the rheological profile curves were also generated by the computer.

\subsection{Statistical Analyses}

The variation in the data collected and the statistical significance of the treatment effect were analyzed by an analysis of variance. Mean comparisons were made by Duncan's test at the 5\% probability level. The statistical data was analyzed using the STATGRAPHICS Centurion XVI.I (16.1.17) (2010) software, Virginia, USA and SigmaPlot 12.1 was used to plot the curves.

\section{Results and Discussion}

\subsection{Influence of Sprouting on Physico-Chemical Characteristics and Functional Properties of Tigernut Tubers}

Table 2 shows that sprouting results in a considerable reduction in the starch content, which is converted into reducing sugars because $66.66 \%$ increases in the concentration of these compounds were observed in the sprouted tubers compared to the native tubers. This observation was also reported by Umerie and Enibelie [9] and Ejoh et al. [20], who recorded a 67.34\% increase in the concentration of reducing sugars after the sprouting of tigernut tubers for syrup preparation.

Table 2. Chemical composition (g/100 gDM) of soaked (SVT), sprouted (ST), and native tubers (NT).

\begin{tabular}{cccc}
\hline Characteristics (g/100 g DM) & Sprouted Tubers & Tubers Treated with Vitamin C & Native Tubers (Control Sample) \\
\hline Water content $(\%)$ & $54.38 \pm 0.54^{\mathrm{b}}$ & $57.34 \pm 0.23^{\mathrm{c}}$ & $7.38 \pm 0.14^{\mathrm{a}}$ \\
Protein & $8.82 \pm 1.31^{\mathrm{a}}$ & $7.42 \pm 0.42^{\mathrm{b}}$ & $7.62 \pm 0.11^{\mathrm{b}}$ \\
Total carbohydrates & $48.93 \pm 1.18^{\mathrm{a}}$ & $47.52 \pm 1.84^{\mathrm{a}}$ & $49.92 \pm 0.12^{\mathrm{b}}$ \\
Reducing sugars & $33.36 \pm 0.35^{\mathrm{a}}$ & $23.74 \pm 1.74^{\mathrm{b}}$ & $20.12 \pm 1.11^{\mathrm{c}}$ \\
starch & $16.63 \pm 0.50^{\mathrm{b}}$ & $25.13 \pm 0.10^{\mathrm{a}}$ & $26.14 \pm 0.27^{\mathrm{a}}$ \\
Lipids & $24.15 \pm 0.02^{\mathrm{b}}$ & $26.25 \pm 0.53^{\mathrm{a}}$ & $25.56 \pm 0.41^{\mathrm{a}}$ \\
Fibers & $15.72 \pm 0.09^{\mathrm{a}}$ & $12.03 \pm 0.94^{\mathrm{c}}$ & $15.56 \pm 0.12^{\mathrm{a}}$ \\
Ashes & $3.84 \pm 0.18^{\mathrm{a}}$ & $1.84 \pm 0.07^{\mathrm{b}}$ & $2.73 \pm 0.31^{\mathrm{a}}$ \\
Vitamin C (mg/100 g) & $275.39 \pm 3.41^{\mathrm{b}}$ & $328 \pm 4.37^{\mathrm{a}}$ & $252 \pm 0.39^{\mathrm{c}}$ \\
Vitamin E (mg/100 g) & $118.73 \pm 0.55^{\mathrm{a}}$ & $118.79 \pm 3.26^{\mathrm{a}}$ & $123 \pm 0.18^{\mathrm{b}}$ \\
Caloric Value (kcal) & 462 & 450 & 445 \\
AA * (U/mL) & $60 \pm 3.72^{\mathrm{a}}$ & $15 \pm 0.58^{\mathrm{b}}$ & $3 \pm 1.69^{\mathrm{c}}$ \\
\hline
\end{tabular}

Results with the same letters exponent on the same line are not significantly different (probability threshold $p \leq 0.05$ )

${ }^{*}$ AA: Amylolytic activity; $U$ (unit of amylase activity): is defined as equivalent to the release of $1 \mu \mathrm{g}$ of glucose per minute and per $\mathrm{mL}$.

This process also increases the protein and ascorbic acid contents from 7.54 to $8.82 \mathrm{~g} / 100 \mathrm{~g}$ DM and 250 to $275.39 \mathrm{mg} / 100 \mathrm{~g} \mathrm{DM}$, respectively. The increase in protein content could be related to the synthesis of enzymes, which are proteins [21]. As for the increase in the ascorbic acid content, Yudkin [22] and Laxmi et al. [23] pointed out that the germination of cereal and legume seeds was accompanied by an increase in the content of ascorbic acid, which in this case would justify the increase in the content of this parameter in the sprouted tubers. However, this treatment causes a slight reduction in lipid contents. This reduction could be explained by the fact that lipids are used to produce the energy necessary for the biochemical and physiological modifications intervening in the tuber during germination $[24,25]$.

The interest in this process has been the stimulation or the synthesis of the amylolytic enzymes. The Table 2 shows that native tubers present only a slight amylolytic activity $(3 \mathrm{U} / \mathrm{mL})$. This activity increases during soaking. The highest activity is observed after tuber germination $(60 \mathrm{U} / \mathrm{mL})($ Table 2$)$. It was found that during this experiment, the amylolytic activity of the sprouted tubers increased from 3 to $60 \mathrm{U} / \mathrm{mL}$, respectively, for NT and ST, which justifies the reduction in starch content and 
increase in the reducing sugar content at the end of germination. These results are similar to those of Traoré et al. [24], Chinma et al. [26], and Ojha et al. [27], who found that the native grains of sorghum, corn, and millet had no amylase activity, while the soaked and sprouted grains developed some amylase activity.

\subsection{Extraction and Physicochemical Characterization of Milks: Influence of In Situ Hydrolysis of Tigernut Starch}

\subsubsection{Extraction Yields of Tigernut Milk}

Figure 2 shows the extraction yields of the tigernut milk obtained at the end of the process. The horchata machine of Spanish origin, used in the conditions of hardened and sprouted tubers, clearly improves the yield of milk extraction from tigernut tubers. The discontinuous process that had been used previously gave $13.79 \%$ yield extracts for the native tubers [2,19], whereas with the horchata machine (H-MP3, MEJISA MECTUFRY, Alicante, Spain), the yield is $45 \%$ for the same type of tubers, and an increase in yield of nearly $69.35 \%$ is observed. The sprouted tubers (ST) and soaked tubers (SVT) gave best yields of, respectively, $72 \%$ and $75 \%$. This could be explained by the fact that these tubers are full of water and this water is found in milky drinks; it also facilitates the extraction of the drink [7]. In addition, soaked tubers (SVT) produce more milk than sprouted tubers (ST); this difference can be justified by the water content of the two types of tubers. Sprouted tubers have a $54.4 \%$ water content while soaked have about $57.3 \%$ [2].

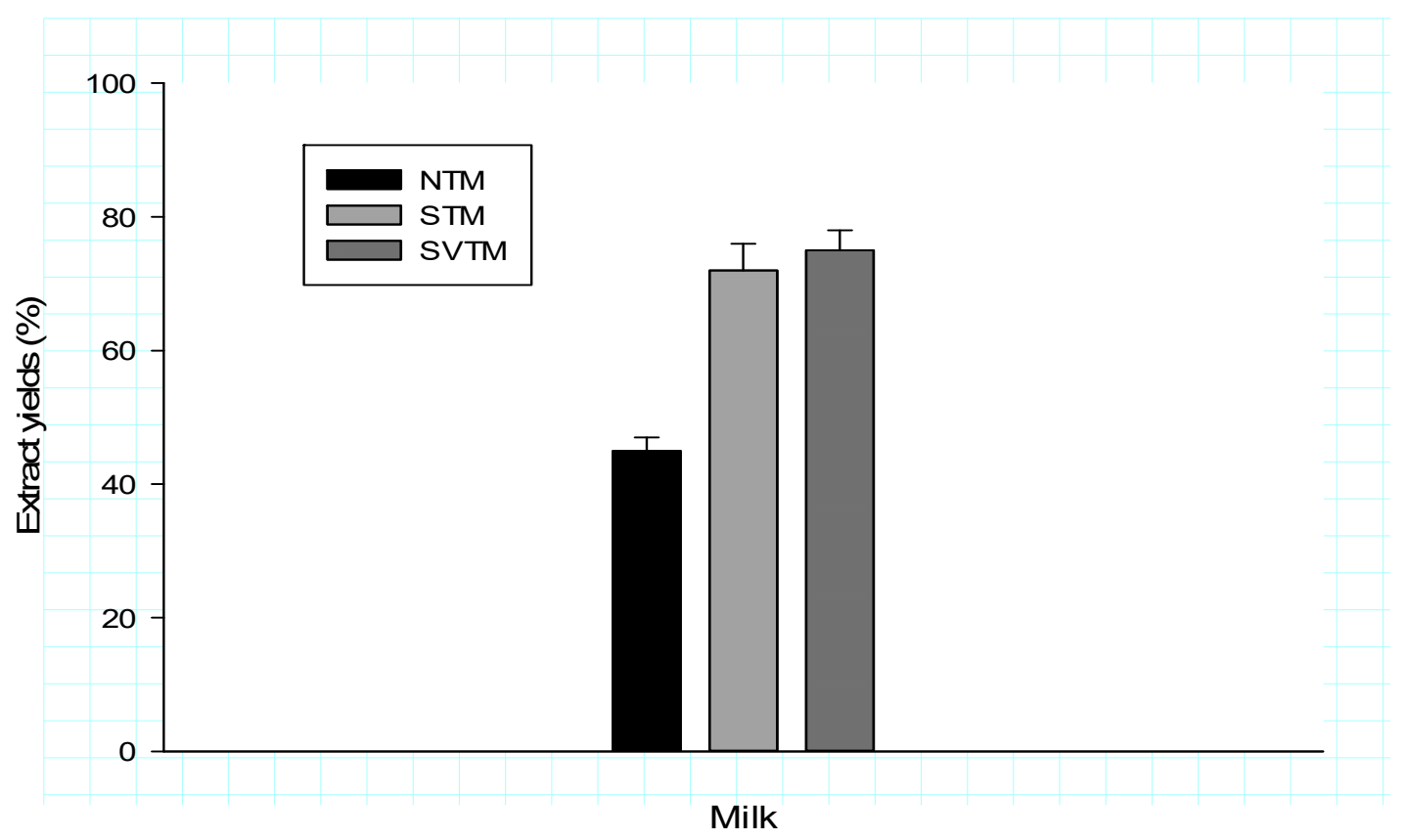

Figure 2. Extraction yields of milky suspensions for different processes applied to tigernut tubers. STM: Sprouted Tuber Milk; SVTM: Soaked in Vitamin C Tuber Milk; NTM: Native Tuber Milk (untreated).

\subsubsection{In Situ Hydrolysis Kinetics of Tigernut Milk Starch}

The hydrolysis of the starch in the milk of tigernut has been carried out using commercial enzymes (Termamyl), which include an alpha amylase and enzymes from the extracts of sprouted tubers. Figure 3 illustrates the starch hydrolysis rate of milk extracts, from native tubers (NTM), tubers soaked in vitamin C solution (SVTM), and sprouted tubers (STM), by these different enzymes. Termamyl has a stronger amylasic activity (85\%) than the amylolytic extracts of sprouted tigernut tubers $(75 \%)$. Termamyl has been used under its optimum conditions of activity, namely at the temperature of $80^{\circ} \mathrm{C}, \mathrm{pH} 6.8$, which is that of tigernut milk, whereas the amylolytic extracts have been applied at the same $\mathrm{pH}(6.8)$ but at a temperature of $45^{\circ} \mathrm{C}$, which corresponds to the maximum 
activity temperature of plant-derived amylases according to the Handbook of Amylases [11] and Klang et al. [28]. Thus, this difference in the rate of hydrolysis can be attributed to the origins of the amylases (one bacterial and the other vegetable), the optimum temperature of activity, the $\mathrm{pH}$ conditions applied, the concentration, and the purity of the various enzymatic extracts.

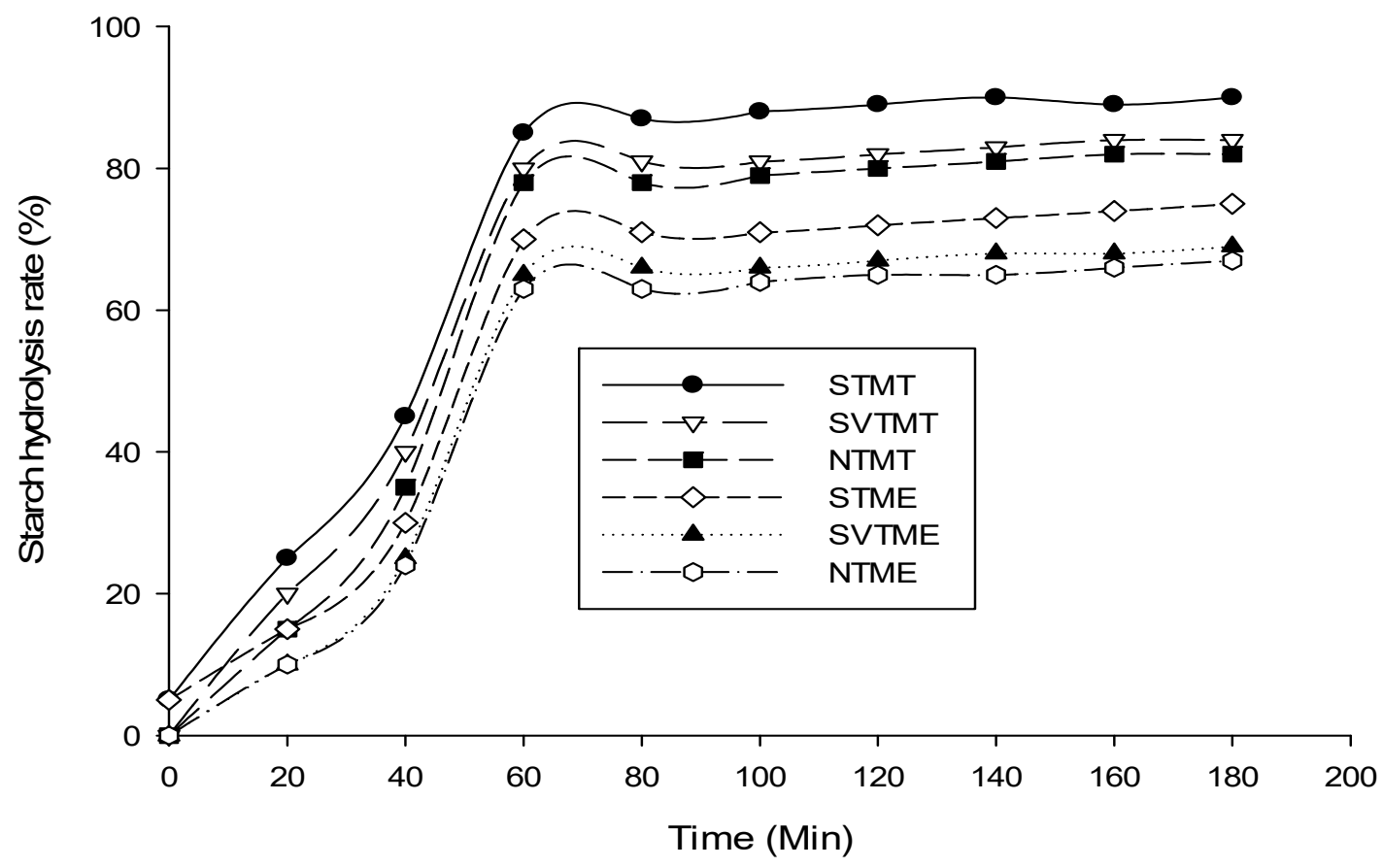

Figure 3. In situ starch hydrolysis rate of milky beverages of tigernut tubers. STMT: Sprouted Tuber Milk treated with Termamyl; SVTMT: Soaked in Vitamin C Tuber Milk treated with Termamyl; NTM T: Native Tuber Milk treated with Termamyl (untreated); STME: Sprouted Tuber Milk treated with amylolytic Extracts; SVTME: Soaked in Vitamin C Tuber Milk treated with amylolytic Extracts; NTME: Native Tuber Milk treated with amylolytic Extracts (untreated).

The time required to achieve maximum starch hydrolysis is approximately $60 \mathrm{~min}$, regardless of the source of amylase (Figure 3). This observation was previously reported by Jaisut et al. [29] and Klang et al. [28], who worked under the same conditions but on rice and sorghum starch respectively. Sprouting induces a decrease in the starch content and significantly influences the rate of starch hydrolysis by enzymes.

\subsection{Chemical Composition of Milks}

The different milky drinks obtained with/without the treatment of tigernut tubers as well as drinks having undergone the in situ hydrolysis of starch were analyzed to determine their chemical composition. Table 3 summarizes the results obtained. Drinks from sprouted tubers have higher protein and ascorbic acid levels of $4.22 \%$ and $54.93 \mathrm{mg} / 100 \mathrm{~mL}$ versus $2.47 \%$ and $23.07 \mathrm{mg} / 100 \mathrm{~mL}$, respectively, for unsprouted tubers. However, their starch and lipid contents are lower than those of native tubers, being $4 \%$ and $6 \%$, respectively, compared with $6 \%$ and $13 \%$.

The milky extracts from tubers soaked in vitamin C solution $(1 \mathrm{~g} / \mathrm{L})$ at $40{ }^{\circ} \mathrm{C}$ have a low fiber content $(0.95 \%$ for SVTM against $2.03 \%$ for NTM), which can be explained by the fact that this treatment leads to the removal of tubercle tuberous, the film that covers the tuber, which has a cellulosic nature, meaning that its loss leads to a decrease in the fibers of the raw material. On the other hand, there is an increase in the ascorbic acid content of the order $75 \%$ relative to the milky extract of the untreated or native tuber, which is due to the phenomena of diffusion of this compound in the tuber during soaking in the vitamin $C$ solution. 
Table 3. Chemical composition of milk extracts from hydrolyzed and unhydrolyzed tigernut tubers, before and after sprouting.

\begin{tabular}{|c|c|c|c|c|c|c|c|}
\hline Parameters (\%) & STM & SVTM & STMT & STME & SVTMT & SVTME & NTM \\
\hline Dry matter & $19.22 \pm 1.63^{c}$ & $18.52 \pm 0.43^{b}$ & $18.78 \pm 1.48^{b}$ & $18.82 \pm 1.93^{b}$ & $18.62 \pm 1.15^{b}$ & $18.56 \pm 1.54^{b}$ & $17.41 \pm 1.52^{a}$ \\
\hline Ashs & $0.92 \pm 0.03^{b}$ & $0.90 \pm 0.09^{b}$ & $0.97 \pm 0.07^{b}$ & $0.94 \pm 0.07^{b}$ & $0.91 \pm 0.08^{b}$ & $0.92 \pm 0.07^{b}$ & $0.70 \pm 0.03^{a}$ \\
\hline Proteins & $4.22 \pm 0.54^{b}$ & $2.45 \pm 0.97^{\mathrm{a}}$ & $3.89 \pm 0.72^{b}$ & $3.75 \pm 0.73^{b}$ & $2.78 \pm 0.54^{a}$ & $2.68 \pm 0.37^{a}$ & $2.47 \pm 0.75^{a}$ \\
\hline Starch & $7.57 \pm 1.44^{b}$ & $12.98 \pm 1.70^{a}$ & $3.85 \pm 1.52^{c}$ & $4.77 \pm 0.95^{\mathrm{c}}$ & $3.96 \pm 0.33^{c}$ & $4.85 \pm 0.59^{c}$ & $12.87 \pm 1.95^{\mathrm{a}}$ \\
\hline Lipids & $4.11 \pm 0.68^{c}$ & $5.83 \pm 0.71^{b}$ & $3.95 \pm 0.22^{c}$ & $4.03 \pm 0.06^{c}$ & $5.06 \pm 0.66^{b}$ & $5.53 \pm 0.74^{b}$ & $6.33 \pm 0.31^{\mathrm{a}}$ \\
\hline $\operatorname{Vitamin} C(\mathrm{mg} / 100 \mathrm{~mL})$ & $54.93 \pm 1.85^{\mathrm{c}}$ & $92.62 \pm 2.22^{a}$ & $12.91 \pm 3.87^{\mathrm{f}}$ & $52.49 \pm 1.19^{c}$ & $17.35 \pm 1.09 \mathrm{e}$ & $91.28 \pm 2.37^{b}$ & $23.07 \pm 1.85^{\mathrm{d}}$ \\
\hline Vitamin E (mg/100 mL) & $7.26 \pm 1.66^{\mathrm{a}}$ & $7.76 \pm 2.65^{\mathrm{a}}$ & $7.37 \pm 1.74^{\mathrm{a}}$ & $6.85 \pm 0.54^{\mathrm{a}}$ & $7.90 \pm 1.74^{\mathrm{a}}$ & $7.94 \pm 1.82^{\mathrm{a}}$ & $6.16 \pm 1.98^{b}$ \\
\hline Fibers & $1.97 \pm 0.54^{\mathrm{a}}$ & $0.95 \pm 0.06^{b}$ & $1.99 \pm 0.08^{a}$ & $1.93 \pm 0.11^{a}$ & $0.97 \pm 0.23^{b}$ & $0.97 \pm 0.05^{b}$ & $2.03 \pm 0.53^{a}$ \\
\hline
\end{tabular}

Results with the same letters exponent on the same line are not significantly different (probability threshold $p \leq 0.05)$. STMT: Sprouted Tuber Milk treated with Termamyl; SVTMT: Soaked in Vitamin C Tuber Milk treated with Termamyl; NTM T: Native Tuber Milk treated with Termamyl (untreated); STME: Sprouted Tuber Milk treated with amylolytic Extracts; SVTME: Soaked in

Vitamin C Tuber Milk treated with amylolytic Extracts; NTME: Native Tuber Milk treated with amylolytic Extracts (untreated). 
The different treatments applied to yellow nutsedge tubers (soaking in the ascorbic acid solution and germination) have an impact on the nutritional quality of beverages obtained from these tubers-in particular, the increase in the ascorbic acid and protein content, respectively, for soaking and germination, and a reduction in fiber in the case of soaking in ascorbic acid solutions, resulting in the peelings of yellow nutsedge tubers. These treatments also have effects on the sweetness of the various milky extracts, and this sweetness is reinforced by the hydrolysis of the starch contained in the beverages, as shown in Figure 5.

\subsection{Sweetness of Milks}

Figure 4 illustrates the evolution of the sweetness of milky drinks from the yellow tigernut tubers following the hydrolysis of starch by Termamyl and amylase extracts. It appears that the sweetness of the drinks varies from 8 to $14^{\circ} \mathrm{Bx}$ as a function of the types of hydrolysis of the C. esculentus starch. The sprouted tubers have a higher sweetness than the non-sprouted tubers (TN) after hydrolysis, these results corroborate those of Otutu et al. [30] and Megat et al. [31]. Hydrolysis with Termamyl induces more free sugars. This process therefore significantly increases the sweetness of beverages compared to the hydrolysis of the amylase extracts of sprouted tubers.

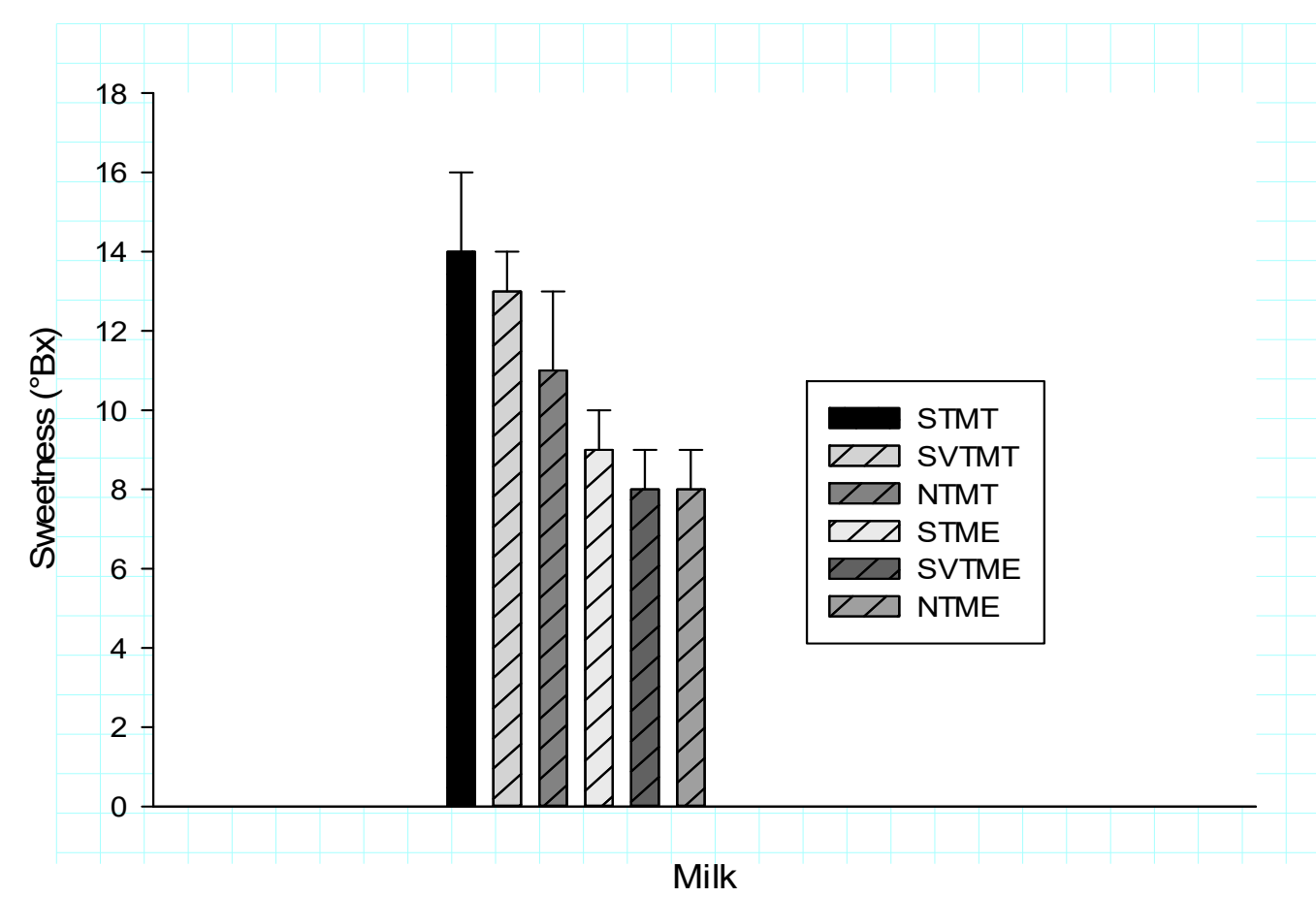

Figure 4. Tigernut milk sweetness during the hydrolysis of starch by amylolytic extracts and Termamyl. STMT: Sprouted Tuber Milk treated with Termamyl; SVTMT: Soaked in Vitamin C Tuber Milk treated with Termamyl; NTM T: Native Tuber Milk treated with Termamyl (untreated); STME: Sprouted Tuber Milk treated with amylolytic Extracts; SVTME: Soaked in Vitamin C Tuber Milk treated with amylolytic Extracts; NTME: Native Tuber Milk treated with amylolytic extracts (untreated).

At the end of these hydrolyses, Figure 4 shows three groups of milky drinks according to their degree of sweetness. The first group consists of beverages extracted from sprouted tubers whose starch has been hydrolyzed using Termamyl, this group has the highest degree of sweetness $\left(14^{\circ} \mathrm{Bx}\right)$. The second group consists of beverages from sprouted tubers whose starch has been hydrolyzed using amylase extracts and native tubers whose starch has been hydrolyzed by Termamyl, which are moderately sweet $\left(11^{\circ} \mathrm{Bx}\right)$. Other drinks have a degree of sweetness below $10^{\circ} \mathrm{Bx}$.

As a result of these treatments, what can be the influences on the rheological profiles of these drinks? 


\subsection{Rheological Profile of Different Milks}

The viscosity profile developed by the milky drinks of tigernut tubers as a function of time and temperature is shown in Figure 4. It represents a typical viscoamylographic characteristic profile of starch.

The rate of solubilization and the swelling phases as well as the temperature of the viscosity peak of tigernut starch are still poorly known. However, the work of Abdel-Akher and Michalinos [32] shows that tigernut starch viscosity is estimated at $2400 \mathrm{mPa}$.s, which is low compared to that of potato starch (7300 mPa.s) and maize (8400 mPa.s).

Under the hydrothermal effects of the treatment, the starch granules of the tigernut tubers begin to hydrate and swell after $200 \mathrm{~s}$, inducing an increase in the viscosity of the suspension. Indeed, when the starch grains are heated to a sufficient temperature in the presence of an excess of water, the water penetrates the grains and causes their swelling (it is gelatinization). When the heating is prolonged, amorphous amylose is solubilized in the medium. The small amylose molecules are more easily released, while temperatures up to $90{ }^{\circ} \mathrm{C}$ are required to have a complete dispersion, including that of amyloses participating in the crystallization of amylopectin. The temperature at which the dispersion of the amyloses begins, which corresponds to the starch temperature of the $C$. esculentus tubers, is obtained at $77.8^{\circ} \mathrm{C}$.

During these phenomena of hydration and swelling of the granules, amorphous amylose is solubilized in the medium constituted by the tigernut tubers milk. The milk obtained is mainly composed of starch; these carbohydrates swell and constitute the dispersed phase and, in some cases, solubilized macromolecules (mainly amylose), which thicken the continuous phase. The rheological properties of the milk depend on the relative importance of these two phases and the swelling volume of the granules.

The viscosity peak is rapidly reached at about $314 \mathrm{mPa} . \mathrm{s}$ at $90.4{ }^{\circ} \mathrm{C}$ for native tuber extracts (NTM) and tubers treated with vitamin C (SVTM). This means that the milk contains a large number of highly swollen starch granules. When maintained at $90^{\circ} \mathrm{C}$, a viscosity break of $312 \mathrm{mPa}$.s appears at $600 \mathrm{~s}$ for NTM and SVTM and $118 \mathrm{mPa} . \mathrm{s}$ for the extracts of sprouted tubers (STM); meanwhile, the hydrolyzed beverages show no change after reaching the viscosity peak at $28 \mathrm{mPa}$.s.

When cooling to $50{ }^{\circ} \mathrm{C}$, a significant increase in viscosity occurs in NTM, SVTM, and STM (336 mPa.s and $122 \mathrm{mPa} . \mathrm{s}$ ). The final viscosities at $50{ }^{\circ} \mathrm{C}$ after $5 \mathrm{~min}$ are at 622, 207, and $27 \mathrm{mPa} . \mathrm{s}$, respectively, for milk from native and soaked tubers (NTM, SVTM), milk from sprouted tubers (STM), and beverages whose starch has been subjected to enzymatic hydrolysis.

In fact, after heating the milky extracts will become, on cooling, more viscous and opaque; if the proportion of amylose is sufficient, it will gel. The firmness of the gel will be greater in the case of drinks obtained from the native and hardened tubers, which contain more amylose than the other extracts, hence the strong demotion of these drinks. There is no difference between the milk extracts from native tubers (NTM) and tubers treated with vitamin C (SVTM) for the hydrothermal characteristics of their starches.

The milky beverages whose starch has been subjected to hydrolysis do not show an increase in viscosity, and all have the same profile irrespective of the type of hydrolysis. These rheological profiles are different from those presented by Abdel-Akher and Michalinos [32], in the sense that these profiles testify to the presence of amylose in the starch structure (strong increase of the viscosity at cooling), whereas these authors had found that this entity would exist in the C. esculentus tubers starch in trace form (less than $1 \%$ ).

The gelatinization temperature, which is defined as the temperature at which $50 \%$ of the grains lose their birefringence in polarized light, is $76^{\circ} \mathrm{C}$ for starch of C. esculentus L., and that of early starch agglutination is $69^{\circ} \mathrm{C}$ according to the work of Umerie and Uka [9]. These results are in line with those obtained in the context of this work, because the start of gelatinization temperature is $81.7^{\circ} \mathrm{C}$. The gelatinization temperature is a function of the size of the starch granules. The smaller the granules, the higher their gelatinization temperature [33]. It is for these reasons that the starch agglutination 
temperature of tigernut tubers milk is up to $90^{\circ} \mathrm{C}$. Hydration of C. esculentus starch granules at low temperatures below $60^{\circ} \mathrm{C}$ is a reversible phenomenon that does not alter the physical properties of this starch. Hence the same gelatinization and starching temperature values for native and soaked tubers.

The results of Figures 3 and 5 show us that tigernut tubers milk containing starch can be subjected to the hydrolysis treatment of this polysaccharide and these drinks can be pasteurized without major gelatinization and retrogradation phenomena. This is an important innovation in the production process of horchata.
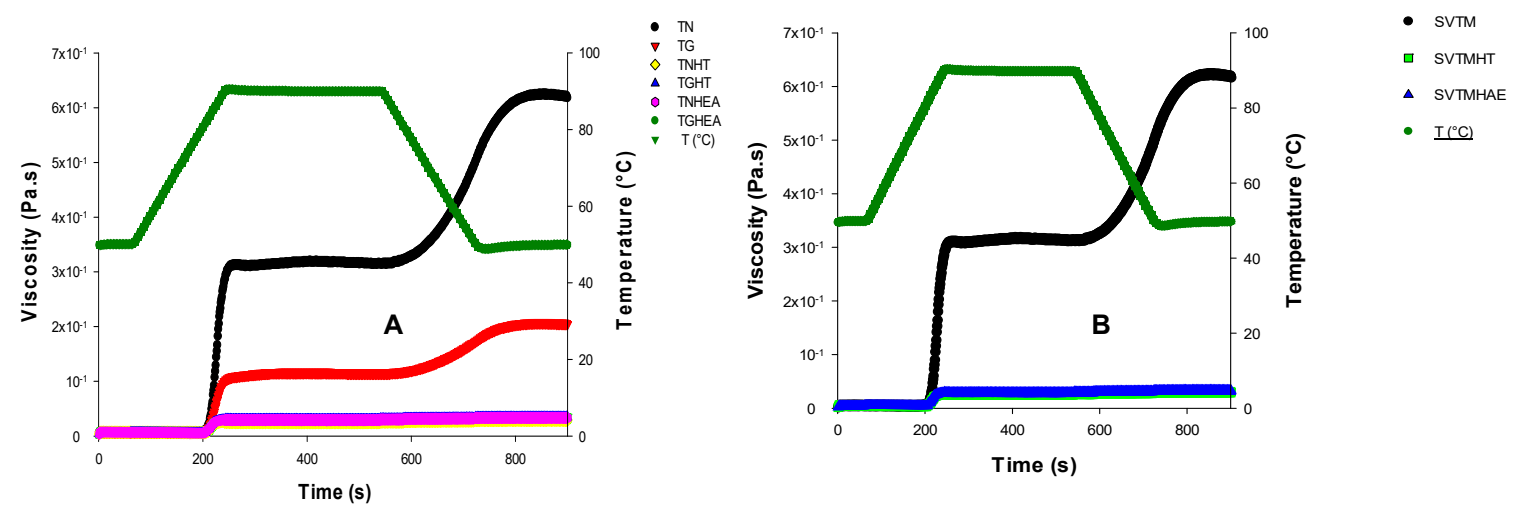

Figure 5. Rheological profile curves of milk extracts from native tubers (A) and tubers treated with vitamin C (B). NTM: Native Tubers Milk; STM: Sprouted Tubers Milk; STMHAE: Sprouted Tubers Milk treated with amylylolitic Extracts; NTMHT: Native Tubers Milk treated with Termamyl; STMHT: Sprouted Tubers Milk treated with Termamyl; NTMHAE: Native Tubers Milk treated with amylolytic Extracts; SVTM: Soaked Vitamin C Tubers Milk; SVTMHT: Soaked Vitamin C Tubers Milk treated with Termamyl and SVTMHAE: Soaked Vitamin C Tubers Milk treated with amylolytic extracts.

\section{Conclusions}

Under this study, the aim of which was to improve the yield and the practice extraction of tigernut milk through the production of this drink from sprouted tubers or by the addition of exogenous amylases, the following conclusions were drawn:

- The soaking and hydrolysis of the starch improves the milk extraction yield to almost $70 \%$ compared to untreated tubers.

- The different types of hydrolysis lead to an increase in the sweetness of the milky extracts.

- Amylolytic hydrolysis significantly reduces the starch content in the milk extracts and makes them suitable for pasteurization without caking tigernut milk, as shown by rheological profiles.

However, it is advisable to study the influence of pasteurization on the shelf life and physical appearance of tigernut milk over time. The influence of pasteurization on the nutritional and organoleptic qualities of the milky extracts after this treatment, as well as the quality of the packaging of treated tigernut milks, remain a scientific concern that will need to be addressed.

Author Contributions: Conceptualization, D. and B.H.; Methodology, D. and B.H.; Software, O.G.; Validation, D. and P.M.; Formal analysis, D.; Investigation, T.T. and G.P.; Resources, D. and C.D.; Data curation, R.E.; Writing-original draft preparation, D. and B.H.; Writing—review and editing, D. and G.P.; Supervision, P.M. and R.N.; Project administration, D. and C.D.; Funding acquisition, D. All authors have read and agreed to the published version of the manuscript.

Funding: This research received no external funding.

Acknowledgments: This work was carried out with the help of the Center for International Cooperation in Agronomic Research for Development (CIRAD) in Montpellier/France and the Inter-establishment Agency for Research for Development (AIRD).

Conflicts of Interest: The authors declare no conflict of interest. 


\section{References}

1. FAO/WHO. FAOSTAT. United Nations Food and Agriculture Organization. 2007. Available online: http: //faostat.fao.org/default.aspx (accessed on 22 June 2019).

2. Djomdi, D.; Ejoh, R.; Ndjouenkeu, R. Soaking behaviour and milky extraction performance of tiger nut (Cyperus esculentus) tubers. J. Food Eng. 2007, 78, 546-550. [CrossRef]

3. Djomdi, D.; Kramer, J.K.G.; VanderJagt, D.J.; Ejoh, R.; Ndjouenkeu, R.; Glew, R.H. Influence of soaking on biochemical components of tiger nut (Cyperus esculentus) tubers cultivated in Cameroon. Int. J. Food Process Eng. 2013, 1, 16-28.

4. Maduka, N.; Ire, F.S. A Review of Some Prevention Strategies against Contamination of Cyperus esculentus and Tigernut Derived Products of Economic Importance. Asian J. Adv. Res. Rep. 2019, 1, 1-13. [CrossRef]

5. Sánchez-Zapata, E.; Fernández-Lopez, J.; Pérez-Alvarez, J.A. Tigernut (Cyperus esculentus) commercialization: Health aspects, composition, properties and food applications. Compr. Rev. Food Sci. Food Saf. 2012, 11, 366-377. [CrossRef]

6. Codina, I.; Trujillo, A.J.; Ferragut, V. Horchata. In Traditional Foods, Integrating Food Science and Engineering Knowledge into the Food Chain; Springer: New York, NY, USA, 2016; p. 348.

7. Adekanmi, O.K.; Oluwatooyin, O.F.; Yemisi, A.A. Influence of processing techniques on the nutrients and antinutrients of tigernut (Cyperus esculentus L.). World J. Dairy Food Sci. 2009, 2, 88-93.

8. Okorie, S.U.; Nwanekezi, E.C. Evaluation of proximate composition and antinutritional factors of Cyperus esculentus (tigernut) as influenced by boiling. IOSR J. Environ. Sci. Toxicol. Food Technol. 2014, 2, 70-73.

9. Umeri, S.C.; Enebeli, J.N. Malt caramel from tubers of Cyperus esculentus. Bioressource Technol. 1996, 2, 215-216. [CrossRef]

10. Garcia-Jimenez, J.; Busto, J.; Vicent, A.; Armengol, J. Control of Dematophora necatrix on Cyperus esculentus tubers by hotwater treatment. Crop Prot. 2004, 23, 619-623. [CrossRef]

11. The Amylase Research Society of Japan. Handbook of Amylases and Related Enzymes; Pergamon Press: Oxford, UK, 1988; pp. 72-75.

12. Goni, I.; Garcia-Alonso, A.; Saura-Calixto, F. A starch hydrolysisprocedure to estimate glycemic index. Nutr. Res. 1997, 17, 427-437. [CrossRef]

13. Bellmer, D.D.; Huhnke, R.L.; Kundiyana, D. Issues with in-field fermentation of sweet sorghum juice. In Proceedings of the 2008 Providence ASABE Meeting, Providence, RI, USA, 29 June-2 July 2008; ASABE: St. Joseph, MI, USA No. 084828.

14. AFNOR, (Association Française de Normalisation). Recueil des normes françaises. In Produit Dérivé des Fruits et Légumes; AFNOR: Paris, France, 2002; p. 260.

15. Edem, D.O.; Ekwere, E.S.; Eke, O.U. Chemical evaluation of the effect of cooking on the nutritive value Conophor seed (Tetraca rpidium conophor). Trop. Sci. 1994, 34, 377-380.

16. UICPA (Union Internationale de Chimie Pure et Appliquée). Méthodes D'analyse des Matières Grasses et Dérivés, 6th ed.; ETIG: Paris, France, 1979; p. 238.

17. Mestres, L.; Mestres, C. Détermination de la teneur en amidon des produits céréaliers fermentés. In African Food Tradition Revisited by Research; Food Research Institute: Zeist, The Netherlands, 2011; FP7 n b245025.

18. Chase, G.; Long, A.R. Liquid chromatographic analysis of all-rac-alpha-tocopheryl acetate, tocopherols, and retinyl palmitate in SRM 1846. J. Liq. Chromatogr. Relat. Technol. 1998, 20, 3317-3327. [CrossRef]

19. AOAC. Official Methods of Analysis of the Association of Official Analytical Chemists; AOAC: Washington, DC, USA, 2000.

20. Ejoh, R.; Djomdi; Ndjouenkeu, R. Characteristics of tigernuts (Cyperus esculentus) tubers and their performance in the production of a milky drink. J. Food Process. Preserv. 2006, 30, 145-163. [CrossRef]

21. Jan, R.; Saxena, D.C.; Singh, S. Physico-Chemical, textural, sensory and antioxidant characteristics of gluten e Free cookies made from raw and germinated Chenopodium (Chenopodium album) flour. LWT Food Sci. Technol. 2017, 71, 281-287. [CrossRef]

22. Yudkin, J. The Penguin Encyclopedia of Nutrition; Penguin Books Ltd.: Middlesex, Harmondsworth, UK, 1988.

23. Laxmi, G.; Chaturvedi, N.; Richa, S. The impact of malting on nutritional composition of foxtail millet, wheat and chickpea. J. Nutr. Food Sci. 2015, 5, 407-419. 
24. Traoré, T.; Mouquet, C.; Icard-Vernière, C.; Traoré, A.S.; Trecie, S. Changes in nutrient composition phytate and cyanide contents and a-amylase activity during cereal malting in small production units in Ouagadougou (Burkina Faso). Food Chem. 2004, 88, 105-114. [CrossRef]

25. Bhathal, S.; Kaur, N. Effect of germination on nutrient composition of gluten free Quinoa (Chenopodium Quinoa). Int. J. Sci. Res. 2015, 4, 423-425.

26. Chinma, C.E.; Anuonye, J.C.; Simon, O.C.; Ohiare, R.O.; Danbaba, N. Effect of germination on the physicochemical and antioxidant characteristics of rice flour from three rice varieties from Nigeria. Food Chem. 2015, 185, 454-458. [CrossRef]

27. Ojha, P.; Adhikari, R.; Karki, R.; Mishra, A.; Subedi, U.; Karki, T.B. Malting and fermentation effects on antinutritional components and functional characteristics of sorghum flour. J. Food Sci. Nutr. 2018, 6, 47-53. [CrossRef]

28. Klang, M.J.; Talamond, P.; Djidimbele, N.; Tavea, F.; Ndjouenkeu, R. Partial purification and characterization of $\alpha$-amylases from Abrus Precatorius, Burnatia Enneandra and Cadaba Farinosa. J. Enzym. Res. 2014, 1, 66-71.

29. Jaisut, D.; Prachayawarakorn, S.; Varanyanond, W.; Tungtrakul, P.; Soponronnarit, S. Effects of drying temperature and tempering time on starch digestibility of brown fragrant rice. J. Food Eng. 2008, 2, 251-258. [CrossRef]

30. Otutu, O.L.; Ikuomola, D.S.; Oloruntoba, R.O. Effect of sprouting days on the chemical and physicochemical properties of sorghum starch. Am. J. Food Nutr. 2014, 4, 11-20.

31. Megat, R.M.R.; Azrina, A.; Norhaizan, M.E. Effect of germination on total dietary fibre and total sugar in selected legumes. Int. Food Res. J. 2016, 23, 257-261.

32. Abdel-Kader; Michalinos. The nutrient content of tigernut (Cyperus esculentus) tubers. J. Food Compos. Anal. 1963, 10, 205-217.

33. Brandama, C.; Meyera, X.H.; Prothb, J.; Strehaianoa, P.; Pingaud, H. An original kinetic model for the enzymatic hydrolysis of starch during mashing. Biochem. Eng. J. 2003, 1, 43-52. [CrossRef]

(C) 2020 by the authors. Licensee MDPI, Basel, Switzerland. This article is an open access article distributed under the terms and conditions of the Creative Commons Attribution (CC BY) license (http://creativecommons.org/licenses/by/4.0/). 